\title{
Ethics of
}

\section{Organ Transplantation}

Center for Bioethics

February 2004 


\section{MEDICAL ISSUES}

What is organ transplantation? .....................................Page 5

The transplant process .............................................. Page 6

Distributing cadaveric organs .....................................Page 7

A history of organ transplantation ..................................Page 9

Timeline of medical and legal advances in organ transplantation...Page 10

\section{ETHICAL ISSUES}

Ethical Issues Part I: The Organ Shortage............................. Page 13

Distribution of available organs ............................... Page 15

Current distribution policy ...................................Page 17

Organ shortage ethical questions ............................. Page 19

Ethical Issues Part II: Donor Organs ................................... Page 20

Cadaveric organ donation ....................................Page 20

Living organ donation ...................................... Page 24

Alternative organs .......................................... Page 27

\section{LEGAL AND SOCIAL ISSUES}

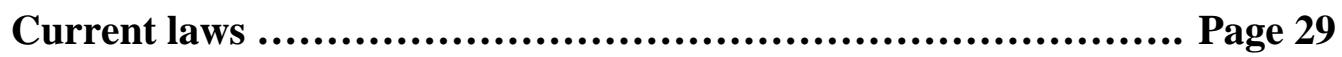

The impact of transplantation ....................................... Page 31

\section{OTHER MATERIALS}

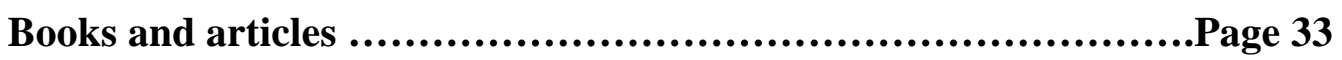

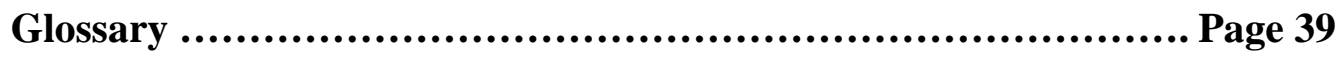

References ....................................................... Page 41 


\section{MEDICAL ISSUES}

\section{What is organ transplantation?}

An organ transplant is a surgical operation

where a failing or damaged organ in the human body is removed and replaced with a new one. An organ is a mass of specialized cells and tissues that work together to perform a function in the body. The heart is an example of an organ. It is made up of tissues and cells that all work together to perform the function of pumping blood through the human body.

Any part of the body that performs a specialized function is an organ. Therefore eyes are organs because their specialized function is to see, skin is an organ because its function is to protect and regulate the body, and the liver is an organ that functions to remove waste from the blood.

A graft is similar to a transplant. It is the process of removing tissue from one part of a person's body (or another person's body) and surgically reimplanting it to replace or compensate for damaged tissue. Grafting is different from transplantation because it does not remove and replace an entire organ, but

WHAT ARE ORGANS?

Solid transplantable organs:

- Heart

- Lungs

- Liver

- Pancreas

- Intestines

Other organs:

- Eyes, ear \& nose

- Skin

- Bladder

- Nerves

- Brain and spinal cord

- Skeleton

- Gall bladder

- Stomach

- Mouth \& tongue

- Muscles rather only a portion.

Not all organs are transplanted. The term "organ transplant" typically refers to transplants of the solid organs: heart, lungs, kidneys, liver, pancreas and intestines. Animal and artificial organs may also serve as transplantable organs. Other types of transplants that are less invasive or may require specialized procedures, include:

- Skin transplants or grafts

- Corneal transplants (corneas are the outer layer of the eye)

- Bone marrow transplants 


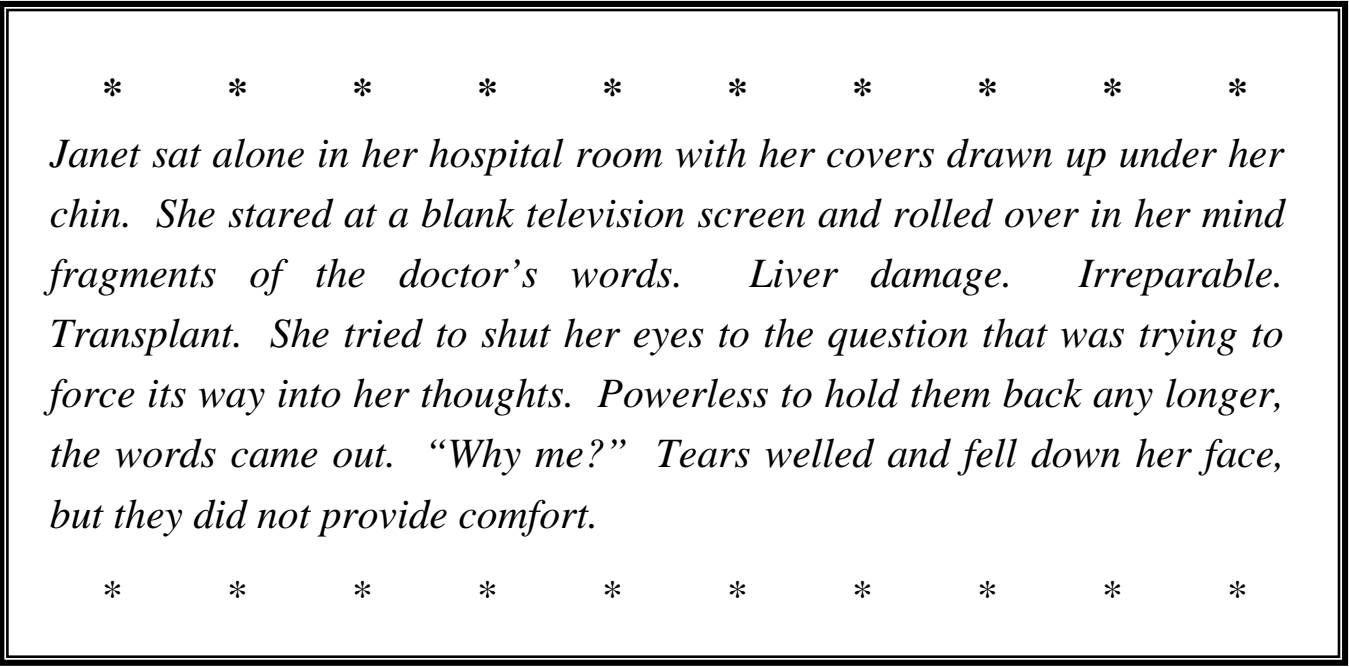

\section{The transplant process}

When a person falls ill because one of his or her organs is failing, or because the organ has been damaged in an accident or by disease, the doctor first assesses whether the person is medically eligible for a transplant. If so, the doctor then refers the individual to a local transplant center. The transplant center evaluates the patient's health and mental status as well as the level of social support to see if the person is a viable candidate for an organ transplant. If the patient is a transplant candidate a donor organ must be found.

There are two sources for donor organs. The first source for organs removes them from recently deceased people. These organs are called cadaveric organs. A person becomes a cadaveric organ donor by indicating that they would like to be an organ donor when they die. This decision can be expressed either on a driver's license or in a health care directive. In Minnesota, designating your organ donation desires on a drivers license is legally binding. ${ }^{1}$

\section{CADAVERIC ORGAN DONATION \\ Organs taken from \\ deceased people are \\ called cadaveric organs. \\ Cadaver is Latin for \\ "a dead body."}

In some states, when a person dies and he or she has not indicated organ donation preferences, the family is asked if they would be willing to donate their relatives' organs. Some states' hospitals have policies requiring family consent for organ removal, regardless of whether organ donation wishes are written down. ${ }^{2}$ Therefore, many organ donation advocacy organizations encourage people to discuss their organ donation preferences with their families to assure that their wishes are known and followed. 
The second source for donor organs is a living person. Living donors are often related to the patient, but that is not always the case. Spouses and close friends frequently donate organs to ailing loved ones.

Some people who wish to donate their organs may decide to donate to a stranger. A few not-for-profit organizations maintain lists of willing living donors. For example, the National Marrow Donor Program maintains a list of people willing to donate bone marrow to a stranger and there are a variety of non-related living kidney donor organizations that maintain regional lists of willing donors. ${ }^{3}$

Individuals who wish to donate one of their organs to a stranger may also initiate a nondirected donation (NDD). Nondirected donors approach either a transplant center or a nationally sponsored organ procurement organization and offer one of their organs for transplant to anyone who may need it. ${ }^{4}$

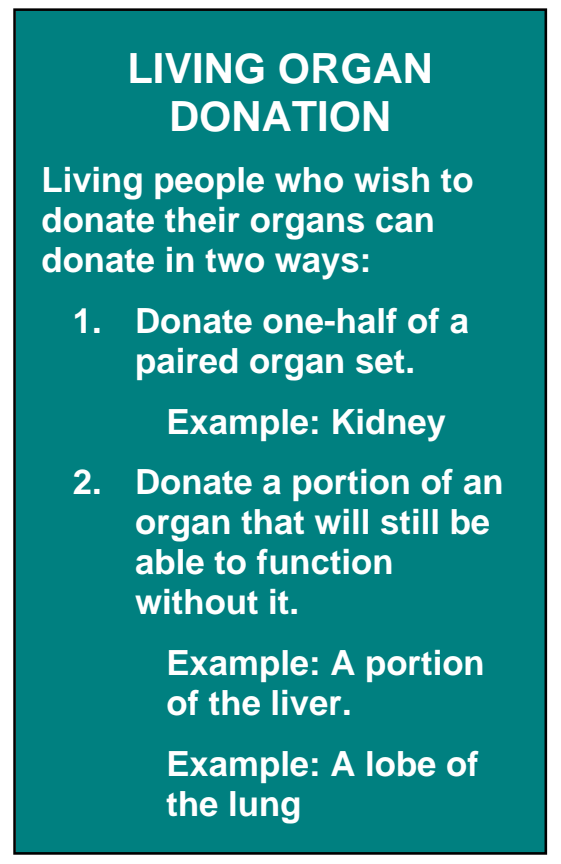

\section{Distributing cadaveric organs}

If a person does not have a readily available living donor or is ineligible for a living donation because their predicted outcome is questionable, they are placed into a waiting pool for an organ from a cadaver by their transplant center. The United Network for Organ Sharing (UNOS) maintains the list for the national waiting pool.

When donor organs become available after a person dies an organ procurement organization (OPO) takes the organs into custody. The OPO then matches the donor organs with the appropriate transplant patients by gathering information about the donor organs and entering it into a computer program. The program takes this information and compares it to information about the patients in the waiting pool. The computer then generates a ranked list of transplant patients who can receive the donor organs.

Information that factors into this ranked list include:

- Organ type, blood type and organ size

- Distance from the donor organ to the patient

- Level of medical urgency (not considered for lung transplant candidates)

- $\quad$ Time on the waiting list ${ }^{5}$ 
After the generation of the ranked list, the donated organ is offered to the first patient's transplant center. However, the first person on the ranked list may not receive the organ. Additional factors to be evaluated before the organ procurement organization selects the appropriate candidate are:

- Is the patient available and willing to be transplanted immediately?

- Is the patient healthy enough to be transplanted?

Once the appropriate candidate is located, the organ procurement organization takes the organ and delivers it to the transplant center where the transplant will be performed. This entire process must occur very quickly as organs are only transplantable for a short time period after they've been removed.

When the transplant patient is ready for the donor organ, the transplant center then surgically removes and replaces the failed or failing organ through the following general procedure:

1. Make an incision in the body near the failing organ

2. Cut the arteries and veins that run to the organ

3. Remove the organ through the incision

4. Take the new organ and insert it into the body through the incision

5. Connect the new organ to the arteries and veins

6. Close the incision

After the transplant, the patient embarks on a long road to recovery. If surgery goes well, the patient still must face the possibility of rejection. Rejection is the process where the body fights off the newly implanted organ.

Rejection is harmful to transplant success because the body fights off the new organ as it would a virus or bacteria. In fact, the body's immune system treats the organ as it would any other harmful foreign invader. The immune system makes proteins called antibodies that go to the transplanted organ and try to kill it.

In order to hold back the antibodies that threaten the new organ, transplant patients have to take powerful immunosuppressant drugs to keep the level of antibodies down low enough for the organ to integrate into the body and start working. ${ }^{6}$ 


\section{A history of organ transplantation}

The medical practice of organ transplantation has grown by leaps and bounds over the last 50 years. The major transplant-related medical advances in the last century include:

- Successful transplantation of different kinds of organs

What began with the kidney has now expanded to hearts, lungs, livers and other organs.

- Development of cadaveric and living organ donation practices

Deciding who can donate organs has been a flexible and changing process, starting with living donors and then moving to include deceased and brain dead donors. The debate about increasing and restricting the pool of eligible donors continues today.

In 2001, living donors outnumbered cadaveric donors for the first time in United States history. ${ }^{7}$

- Development of anti-rejection drugs to increase success

Anti-rejection drugs have done wonders to increase the success of organ transplants. During the 1960s and 1970s, immunosuppressant drugs helped increase the success rate of organ transplants.

In the 1980s, Cyclosporine was discovered and dramatically improved the success rate for transplant recipients and helped improve patient outcomes. $^{8}$

- Using animal organs for human transplantation (called xenotransplantation)

In 1986, the first xenotransplanted organ transplant was performed. This intriguing field of study becomes more attractive to some researchers as the number of people needing organ transplants continues to grow.

- Invention and use of the first artificial organs

The first artificial heart transplant in the 1980s was closely followed by the news media and the American public.

- Splitting organs into pieces (either from living donors or cadaveric donors)

The first split liver transplant in 1996 allowed one cadaveric liver to be used among multiple transplant patients.

- Stem cell research

Stem cell research is examining adult and human embryo cells in an attempt to discover how organs are developed and what stimulates their growth. 
TIMELINE OF MEDICAL AND LEGAL ADVANCES IN ORGAN TRANSPLANTATION

\begin{tabular}{|c|c|c|}
\hline & MEDICAL ADVANCES & LEGAL ADVANCES \\
\hline 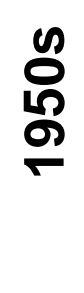 & $\begin{array}{l}1954 \\
\text { The first successful kidney } \\
\text { transplant. A kidney is taken } \\
\text { from one identical brother } \\
\text { and transplanted in another, } \\
\text { where it worked for } 8 \text { years. }\end{array}$ & \\
\hline $\begin{array}{l}0 \\
8 \\
0 \\
0\end{array}$ & $\begin{array}{l}1962 \\
\text { The first successful } \\
\text { cadaveric transplant used a } \\
\text { deceased donor kidney. The } \\
\text { kidney worked for almost } 2 \\
\text { years. } \\
1966 \\
\text { First successful liver } \\
\text { transplant. The liver worked } \\
\text { for over one year. }{ }^{11} \\
1967 \\
\text { First successful heart } \\
\text { transplant. The heart worked } \\
\text { for } 2 \frac{1}{2} \text { weeks. }{ }^{12}\end{array}$ & \\
\hline$\underset{\infty}{\infty}$ & & $\begin{array}{l}1972 \\
\text { The Uniform Organ Donor Card was } \\
\text { established as a legal document in } \\
\text { all } 50 \text { states due to the passage of } \\
\text { the Anatomical Gift Act. This act } \\
\text { allowed anyone over } 18 \text { to legally } \\
\text { donate their organs. }{ }^{13} \\
1972 \\
\text { End Stage Renal Disease Act led to } \\
\text { insurance coverage for kidney } \\
\text { transplants under Medicare. }{ }^{14}\end{array}$ \\
\hline
\end{tabular}




\begin{tabular}{|c|c|c|}
\hline & MEDICAL ADVANCES & LEGAL ADVANCES \\
\hline 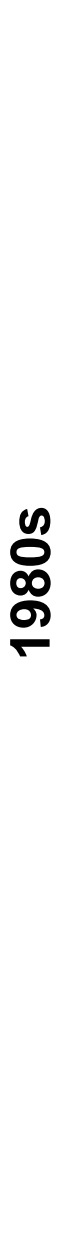 & $\begin{array}{l}1981 \\
\text { First successful heart-lung } \\
\text { transplant. The organs worked } \\
\text { for } 5 \text { years. }{ }^{15} \\
1982 \\
\text { First artificial heart transplant. }{ }^{16} \\
1983 \\
\text { Cyclosporine, an } \\
\text { immunosuppressant drug, was } \\
\text { approved by the FDA. }{ }^{17} \\
1986 \\
\text { A baboon heart was transplanted } \\
\text { into Baby Faye and worked for } 20 \\
\text { days. }{ }^{18} \\
1989 \\
\text { The first successful living-related } \\
\text { liver transplant. }\end{array}$ & $\begin{array}{l}1981 \\
\text { President's Commission drafted the } \\
\text { Uniform Determination of Death Act } \\
\text { (UDDA) which included irreversible } \\
\text { brain death as a criteria for death. } \\
1984 \\
\text { The National Organ Transplant Act } \\
\text { (NOTA) passed. NOTA established } \\
\text { the United Network for Organ } \\
\text { Sharing (UNOS), allowed financing } \\
\text { for organ procurement } \\
\text { organizations, and prohibited the } \\
\text { sale of organs." } \\
1986 \\
\text { The Omnibus Reconciliation Act of } \\
1986 \text { passed and included "required } \\
\text { request." This legally required all } \\
\text { hospitals treating Medicare or } \\
\text { Medicaid patients to ask the next of } \\
\text { kin about donating their loved one"s } \\
\text { organs. }\end{array}$ \\
\hline 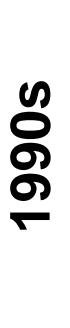 & $\begin{array}{l}1996 \\
\text { The first "split liver" transplant } \\
\text { was performed where one } \\
\text { cadaveric liver was split into } \\
\text { several pieces to transplant into } \\
\text { more than one person. }\end{array}$ & $\begin{array}{l}1998 \\
\text { The Department of Health and } \\
\text { Human Services required organ } \\
\text { procurement organizations to be } \\
\text { notified of every hospital death. }\end{array}$ \\
\hline$\stackrel{0}{8}$ & $\begin{array}{l}2000 \\
\text { First culture of human embryonic } \\
\text { stem cells. } \\
2001 \\
\text { Number of living organ donations } \\
\text { passed cadaveric donations. }\end{array}$ & \\
\hline
\end{tabular}




\section{ETHICAL ISSUES}

\section{ETHICAL ISSUES PART I: THE ORGAN SHORTAGE}

The primary ethical dilemmas surrounding organ transplantation arise from the shortage of available organs. ${ }^{25}$ Not everyone who needs an organ transplant gets one and in fact, the scales tip quite heavily in the opposite direction.

The United Network for Organ Sharing (UNOS) maintains a comprehensive, upto-date website that gives the status of people awaiting organ transplants. According to their website (updated daily at www.unos.org) over 83,000 people are currently awaiting transplants in the United States.
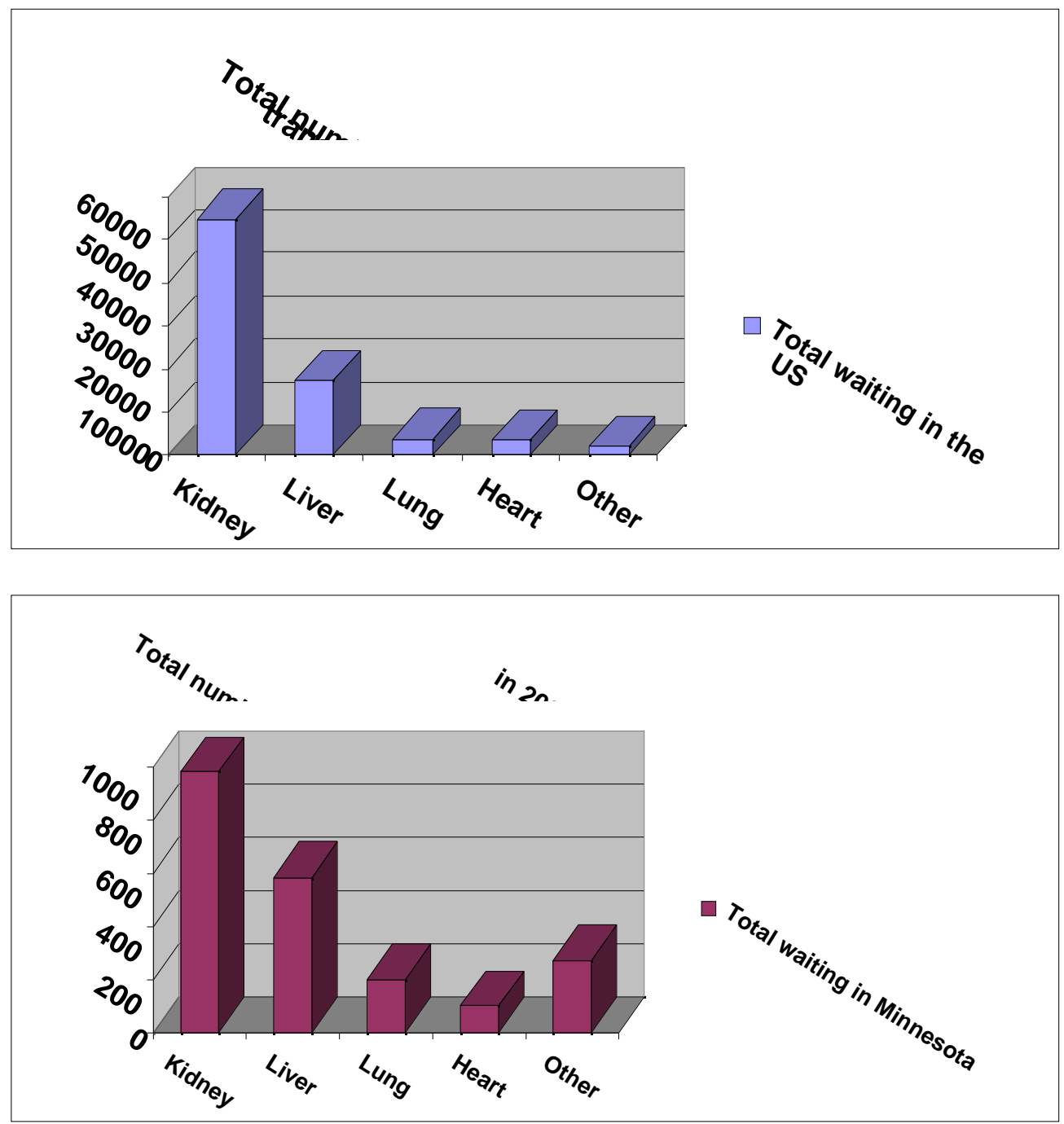
The UNOS website reports that in 2003 more than 19,000 organ transplants were performed. The organs were taken from approximately 9,800 donors both living and deceased. While 19,000 transplants may seem like a large number, 83,000 people remain on the waiting list for an organ and the gap between the number of available donor organs and the number of people who need organs grows daily.

The following information from www.unos.org gives an idea of the extent of the organ shortage:

- "On average, 106 people are added to the nation's organ transplant waiting list each day--one every 14 minutes.

- $\quad$ On average, 68 people receive transplants every day from either a living or deceased donor.

- "On average, 17 patients die every day while awaiting an organ -- one person every 85 minutes. In 2002, 6,187 individuals died on the U.S. organ transplant waiting list because the organ they needed was not donated in time." 26

\begin{tabular}{||c|}
\hline$*$ * * * \\
Melissa received a phone call \\
one evening from the hospital. \\
Her 17 year old son had been \\
in a car crash and was in \\
critical condition. When she \\
arrived, she was told he was \\
brain dead. Meliss's mind \\
starting reeling. "This can't \\
be happening," she told \\
herself. But it had happened. \\
As she walked into the trauma \\
room, the doctor said he'd join \\
her in a few minutes to talk \\
about organ donation. Silently, \\
Melissa nodded and walked \\
into the room to see her son. \\
* * * * ${ }^{*}$ \\
\hline
\end{tabular}

The number of donated organs has stayed fairly constant over the last few years while the number of people needing organs continues to increase. ${ }^{27}$ Many explanations are offered to explain the length of the list - such as the number of new medical technological advances and the aging population.

One possible explanation as to why the number of donated organs from cadavers remains static concerns the increasing effectiveness of seat belt campaigns and air bag use. In the past, a large source of healthy cadaveric organs came from victims of car crashes. ${ }^{28}$ With static or declining numbers of car crash fatalities, there are also declining sources of healthy human organs for transplant. ${ }^{29}$ 


\section{Distribution of available organs}

The concept of distributive justice - how to fairly divide resources - arises around organ transplantation because there are not enough organs available for everyone who needs one. Distributive justice theory states that there is not one "right" way to distribute organs, but rather many ways a person could justify giving an organ to one particular individual over someone else. ${ }^{30}$ This list of possible distributive justice criteria comes from the University of Washington School of Medicine website:
1. To each person an equal share
2. To each person according to need
3. To each person according to effort
4. To each person according to contribution
5. To each person according to merit
6. To each person according to free-market exchanges ${ }^{31}$

One distributive justice criteria is equal access. Organs allocated according to equal access criteria are distributed to patients based on objective factors aimed to limit bias and unfair distribution. Equal access criteria include:

- Length of time waiting (i.e. first come, first served)

- $\quad$ Age (i.e. youngest to oldest)

Equal access supporters believe that organ transplantation is a valuable medical procedure and worth offering to those who need it. They also argue that because the procedure is worthy, everyone should be able to access it equally. ${ }^{32}$ To encourage equality in organ transplantation, the equal access theory encourages a distribution process for transplantable organs that is free of biases based on race, sex, income level and geographic distance from the organ. ${ }^{33}$

Some who believe in equal access distribution would also like to have an organ distribution process free of medical or social worthiness biases. Medical "worthiness" biases could exclude patients from reaching the top of the transplant waiting list if lifestyle choices like smoking and alcohol use damaged their organs. Social "worthiness" biases would factor in a patient's place in society or potential societal

SUPPORTERS OF EQUAL ACCESS DISTRIBUTION SAY...

Everyone should have equal access

to organs because everyone could potentially benefit from the system. 
contribution before giving them an organ. This would affect, among others, prisoners being punished for offenses against society.

The primary reasons for wanting to prevent individual worth from factoring into organ distribution include: a) the argument that individual worth does not determine medical need; b) the dilemma involved in deciding who will make decisions of who is worthy or not worthy to receive an organ, and; c) the slippery slope of determining an individual's worth and whether or not it is fair to label someone worthy of a medical procedure. $^{34}$

\section{Recent research shows that when given scenarios of two people who both need an organ transplant, the general public's organ distribution preferences are influenced by whether or not a person made behavioral lifestyle choices that caused their illness.}

${ }^{1}$ Ubel PA, Jepson C, Baron J, et.al. Allocation of transplantable organs: do people want to punish patients for causing their illness? Liver Transplant, 2001; 7(7):600-7.
On the other hand, some ethicists argue that individual worth is important to consider during organ distribution. They argue that distribution is biased against worthy individuals when individual worthiness factors are not included.

One example of this argument comes from a 1990s article in the Canadian Medical Association Journal by E. Kluge. Kluge argues that equal access distribution of organs is not fair and just if it includes people whose lifestyle choices, namely tobacco and alcohol use, ruined their organs. Kluge's argument states that people who engage in poor lifestyle choices are behaving irresponsibly and could have

prevented their illness and are, in essence, increasing the need for organs and depriving people who, "have no control over their need," of necessary treatment. ${ }^{35}$

A second type of distributive justice criteria is maximum benefit. The goal for maximum benefit criteria is to maximize the number of successful transplants. Examples of maximum benefit criteria include:

- Medical need (i.e. the sickest people are given the first opportunity for a transplantable organ)

- Probable success of a transplant (i.e. giving organs to the person who will be most likely to live the longest)

People who support the maximum benefit philosophy believe organ transplants are medically valuable procedures and wish to avoid the wasting of organs because they are very scarce. ${ }^{36}$ To avoid waste, they support ranking transplant candidates by taking 
into account how sick the patient is and how likely it is that the patient will live after he or she receives a transplant.

Successful transplants are measured by the number of life years gained. Life years are the number of years that a person will live with a successful organ transplant that they would not have lived otherwise. This philosophy allows organ procurement organizations to take into account several things when distributing organs that the equal access philosophy does not - like giving a second organ transplant to someone who's already had one or factoring in the probability of a successful medical outcome. $^{37,38}$

Three primary arguments oppose using the maximum benefit distribution criteria. First, predicting medical success is difficult because a successful outcome can vary. Is success the number

SUPPORTERS OF MAXIMUM BENEFIT DISTRIBUTION SAY...

Organs should be distributed so that the greatest benefit is derived from every available organ

of years a patient lives after a transplant? Or is success the number of years a transplanted organ functions? Is success the level of rehabilitation and quality of life the patient experiences afterward? These questions pose challenges to those attempting to allocate organs using medical success prediction criteria. ${ }^{39}$

The second argument against maximum benefit distribution is that distributing organs in this way could leave the door open for bias, lying, favoritism and other unfair practices more so than other forms of distribution due to the subjective nature of these criteria. ${ }^{40}$ Third, some ethicists argue against using age and maximizing life years as criteria for distributing organs because it devalues the remaining life of an older person awaiting a transplant. Regardless of how old someone is, if that person does not receive a transplant they will still be losing "the rest of his or her life," which is valuable to everyone. $^{41}$

\section{Current organ distribution policy}

The current organ distribution method in the United States relies on each transplant center to determine which criteria they will use to fairly allocate organs. ${ }^{42}$ UNOS encourages transplant centers to consider the following criteria for distributing organs: 1) medical need; 2) probability of success, and; 3) time on the waiting list. ${ }^{43}$ According to a 2001 article by James Childress, most experts agree that these three criteria are relevant. Childress states that ethical conflicts arise both when specifying what the criteria mean, and when weighing the criteria in cases of conflict. ${ }^{44}$ 
Dr. Jeffrey Kahn, in his on-line articles for CNN's Ethics Matters series (www.cnn.com/HEALTH/bioethics/) argues that the imperfections in organ distribution come from the scarcity of donor organs. Kahn says that if Americans wish to support organ transplantation as a medical procedure, then they must be sensitive to the fact that politics and biases will probably factor into any ranking system until there are enough organs to go around:

"Policies need to be aimed at both increasing organ donations as well as creating a system that allocates them in the fairest ways possible." ${ }^{45}$

Not everyone believes in the need to increase the number of organ transplants. There are some who believe that organ transplantation inappropriately encourages the medicalization of society. In fact, one on-line website suggests that organ transplants are merely one way in which United States citizens attempt to transcend death. ${ }^{46}$

A second point of view that questions increasing the practice of organ transplantation relies on the assumption that resources for health care are scarce and organ transplants are costly. The questions this raise include - what is the social worth of organ transplants and are they diverting money from other necessary medical care $?^{47}$

Finally, a recent article suggested that not enough research has been conducted on poor transplant outcomes. The authors suggest that unsuccessful transplant patients continue to receive aggressive, curative treatment when they should be receiving more caring and holistic treatment. ${ }^{48}$ 


\section{ORGAN SHORTAGE: ETHICAL QUESTIONS}

Transplantable organs are scarce. Knowing that there are more people who need organs than there are organs available, how would you answer the following questions? Are your answers based on a belief of equal access or maximum benefit distribution?

1. Should someone who has received one organ transplant be given a second transplant? Or should people who have not had a transplant be given priority over those who have already had one?

2. Should people whose lifestyle choices (smoking, drinking, drug use, obesity, etc.) damaged their organ be given a chance at an organ transplant?

3. Should suicidal individuals be given an organ transplant? What if they attempted suicide in the past but are not currently contemplating suicide?

4. Should people who have young children be given an organ transplant over a single person? Over an elderly person? Should age and whether or not a person has children even matter?

5. Should people who can't afford expensive anti-rejection drugs be passed over for a transplant? Should people who don't have insurance and can't pay for a transplant be allowed to go on the national waiting list?

6. Should condemned prisoners receive organ transplants? What if they are serving a life sentence without parole? 


\section{ETHICAL ISSUES PART II: DONOR ORGANS}

One way to avoid the ethical problems associated with the shortage of transplantable organs is to increase the number of donor organs. However, fears abound that policies to maximize organ donations could go too far - leading to organ farming or premature declarations of death in order to harvest organs.

Many, if not most, people agree that taking organs from any source is a justifiable practice within certain ethical boundaries. Controversies result from an inability to define exactly where those boundaries lie. ${ }^{49}$ Everyone may have their own unique ideas about the boundaries they would like to see concerning the following three sources of transplantable organs: cadaveric donors, living donors and alternative organ sources.

\section{Cadaveric organ donation}

Currently, once a person dies, his or her organs may be donated if the person consented to do so before they passed away. A person's consent to donate their organs is made while still living and appears on a driver's license or in an advance directive. After consenting to donate organs, nothing happens with that information until the person dies. A person is considered dead once either the heart stops beating or brain function ceases (called brain death). After death, the organs are taken from the deceased person's body. If possible, the deceased person may be kept on life support once they have died until the organs can be taken, in order to preserve the organs until they are removed.

If the deceased person's organ donation wishes are unknown, the hospital, physician, or organ procurement organization will approach a family member to obtain consent to remove the organs. The family members with the authority to do so is generally determined by this hierarchy:

- Spouse. If no spouse, then...

- Adult child. If no adult children, then...

- Parent. If no parents, then...

- Adult sibling. If no siblings, then...

- Legal guardian. ${ }^{50}$

One cadaveric donor can provide organs for several different people. Which organs and tissues can be recovered may depend on the cause of death or damage to an organ, but typically several organs can be recovered from a single cadaver. In 2002, more than 22,000 organs were recovered from 6,182 cadaveric donors. ${ }^{51}$ 
Five strategies to increase cadaveric organ donations

Since one cadaveric donor can provide multiple organs, this is a natural place to look to increase the number of available organs. Efforts to increase the number of cadaveric donors have met with much debate and controversy. There are five primary strategies currently under consideration for the future.

\section{Strategy to increase cadaveric organs: Education}

Education is the first strategy suggested by many to increase cadaveric organ donation. Some

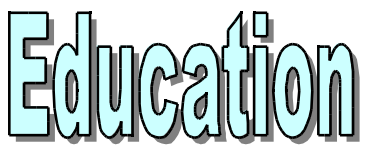
educational efforts focus on increasing the number of people who consent to be an organ donor before they die. Other educational efforts focus on educating families when they are considering giving consent for their deceased loved one's organs. Social responsibility and the idea of "the gift of life" are popularized by UNOS and other organizations that seek to promote the idea of cadaveric organ donation.

\section{Strategy to increase cadaveric organs: Mandated choice}

A second potential strategy to increase organs from cadaveric donors is mandated choice. Under this strategy, every

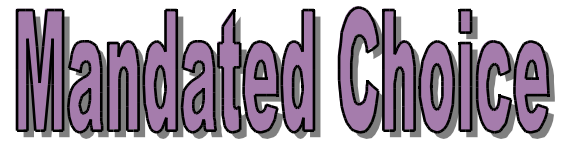
American would have to indicate their wishes regarding organ transplantation, perhaps on income tax forms or drivers licenses. When a person dies, the hospital must comply with their written wishes regardless of what their family may want. The positive aspect of this strategy is that it strongly enforces the concept of individual autonomy of the organ donor.

A mandated choice policy would require an enormous level of trust in the medical system. People must be able to trust their health care providers to care for them no matter what their organ donation wishes. A 2001 survey of 600 family members who had experience donating organs from a deceased loved one, found about $25 \%$ of respondents would be concerned that a doctor wouldn't do as much to save their loved one's life if they knew they were willing to donate their organs. ${ }^{52}$

A mandated choice policy was tested in Texas during the 1990's. When forced to choose, almost $80 \%$ of the people chose NOT to donate organs, which was not an increase in the number of available organs. The law enacting mandated choice for Texans has since been repealed. ${ }^{53}$ 


\section{Strategy to increase cadaveric organs: Presumed consent}

Presumed consent is a third strategy aimed to increase cadaveric organ donation. This method of procuring organs is in fact

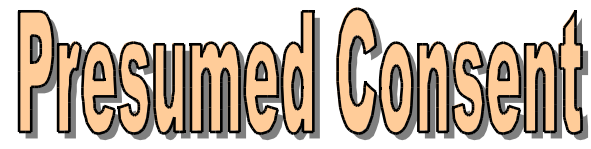
the policy of many European nations. ${ }^{54}$ In countries with presumed consent, their citizens' organs are taken after they die, unless a person specifically requests to not donate while still living.

Advocates of a presumed consent approach might say that it is every person's civic duty to donate their organs once they no longer need them (i.e. after death) to those who do. People against presumed consent would argue that to implement this policy, the general public would have to be educated and wellinformed about organ donation, which would be difficult to adequately achieve. ${ }^{55}$

Doubters of the presumed consent approach might also argue that requiring people to opt out of donating their organs requires them to take action and this might unfairly burden some people. There are worries that people who frequently choose not to donate organs for religious and cultural reasons (minority cultural groups and immigrants, primarily) might find it the most challenging to opt out of donating due to language barriers, transportation difficulties or for other reasons. ${ }^{56}$

\section{Strategy to increase cadaveric organs: Incentives}

The fourth strategy under consideration to increase cadaveric organ donation is the use of

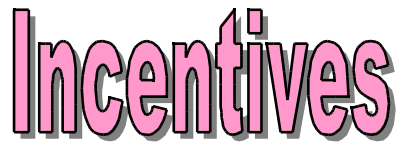
incentives. Incentives take many forms. Some of the most frequently debated incentive strategies are:

1. Give assistance to families of a donor with funeral costs

2. Donate to a charity in the deceased person's name if organs are donated

3. Offer recognition and gratitude incentives like a plaque or memorial

4. Provide financial or payment incentives

One of the most highly debated incentives would give donating families assistance with burial or funeral costs for their loved one. With funerals costs in the thousands, this could be an attractive incentive for many families. The majority of members of the American Society of Transplant Surgeons support 
funeral reimbursement or charitable organization donation as a strategy to increase donation. ${ }^{57}$

Many people favor charitable donation or recognizing donors as an incentive for organ donation. Some argue that providing recognition of a donor is not really an incentive at all, but merely an appropriate response to a very generous donation. Another twist on this group of incentives is offering recognition or charitable donation to people while they are living to encourage them to donate. Proponents say that since the person will be dead and unable to receive the recognition, that this would not be a coercive action. ${ }^{58}$

Some ethicists believe that many of the incentives above, while not attached directly to cash money, are still coercive and unfair. They believe that some people will be swayed to donate, in spite of their better judgment, if an incentive is attractive enough. They further argue that a gesture may seem small and a mere token to one person, but others might interpret it quite differently. ${ }^{59}$

A final anti-incentives argument offered by some ethicists discourages the practice of incentivizing organ donation. They believe that society should instead re-culture its thinking to embrace a communitarian spirit of giving and altruism where people actively want to donate their organs. ${ }^{60}$

\section{Strategy to increase cadaveric organs: Prisoners}

The final strategy under consideration to increase the number of available cadaveric organs is to use

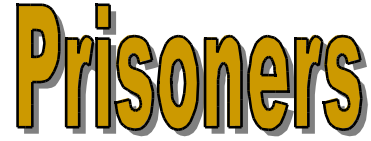
organs taken from prisoners who are put to death. One argument in favor of taking organs from prisoners who are put to death, is that it is the execution that is ethically unsound and not the organ removal. ${ }^{61}$ Indeed, in light of the severe organ shortage, some ethicists could make the argument that to not use the organs for transplantation is wasteful. ${ }^{62}$ John Robertson, in a 1999 article, put forth the argument that obtaining organs from condemned prisoners is allowable if the prisoner or their next of kin consents to donation, as long as organ donation is not the means by which the prisoner is killed because that violates the principle that a cadaveric donor be dead prior to donation. ${ }^{63}$ Finally, some could argue that organ retrieval from executed prisoners is morally justifiable only if a "presumed consent" donation practice was in place. ${ }^{64}$

Many, if not most, bioethicists consider taking organs from condemned prisoners a morally objectionable practice. Colorful language used by some ethicists includes the following words to describe the practice: "immoral," "repugnance," and "revulsion." 65,66 


\section{Living organ donation}

A person with organ damage or organ failure may look for a living donor to donate an organ, allowing the patient to bypass the national waiting pool to receive a cadaveric organ. According to UNOS, there are a number of benefits to living donation, both for the donor and the patient:

- The donation can be pre-arranged, allowing the patient to begin taking antirejection drugs in advance, thereby increasing the chances of success

- There are often better matches between donors and recipients with living donation, because many donors are genetically related to the recipient

- Psychological benefits for both the donors and recipients ${ }^{67}$

Not everyone encourages the practice of living donation for all people. Drawbacks to becoming a living donor may include:

- Health consequences: Pain, discomfort, infection, bleeding and potential future health complications are all possible ${ }^{68}$

- Psychological consequences: Family pressure, guilt or resentment ${ }^{69}$

- Pressure: Family members may feel pressured to donate when they have a sick family member or loved one ${ }^{70}$

- No donor advocate: While the patients have advocates, like the transplant surgeon or medical team (who are there to advise the patient and work in favor of his or her best interests) donors do not have such an advocate and can be faced with an overwhelming and complicated process with no one to turn to for guidance or advice ${ }^{71}$

A few medical and ethical professionals argue that living donation is inappropriate under any circumstances and should not only be discouraged but abandoned all together because of the risk and dangers associated with donating organs. ${ }^{72}$ Other critics seek to discourage living donation because they think extending life through costly and physically taxing medical procedures is not the purpose of health and healthcare in America. ${ }^{73}$

Although there are some who object to the practice of living donation, this potential source of organs is currently a major focus as a way to reduce the shortage of organs in America. Increasing the number of living donors could occur through a variety of strategies from education and civic duty promotion to the sale and purchase of organs. 
There are a few non-financial incentives available as options to increase living donation, such as medical leave or special insurance for living donors. ${ }^{74}$ The idea of nonfinancial incentives may be rising in popularity as a way to entice people to donate their organs. In January of 2004, Wisconsin became the first state to offer a living donation incentive to its citizens. The new law allows living donors in Wisconsin to receive an income tax deduction to recoup donation expenses like travel costs and lost wages. ${ }^{75}$

Financial incentives aimed at encouraging living donation have received much attention from bioethicists lately. Most experts argue that buying and selling human organs is an immoral and disrespectful practice. ${ }^{7677}$ The moral objection raised most often argues that selling organs will appeal to the socioeconomically disadvantaged (people who are poor, uneducated, live in a depressed area, etc.) and these groups will be unfairly pressured to sell their organs by the promise of money. This pressure could also cause people to overlook the possible drawbacks in favor of cash incentives. On the other hand, wealthy people would have unfair access to organs due to their financial situations.

The current United States policy does not allow for the sale of human organs. The

BUYING AND SELLING ORGANS

Paying people to donate their kidneys is one of the most contentious ethical issues being debated at the moment. The most common arguments against this practice include:

- Donor safety

- Unfair appeal of financial incentives to the economically disadvantaged

- Turning the body into a money-making tool

- Wealthy people would be able to access more readily

National Organ Transplant Act of 1984 banned such a practice. ${ }^{78}$

In 2002, an article that examined the effects of offering payment for kidneys in India was published in the Journal of the American Medical Association. Although critics pointed to a variety of methodological issues. The findings uncovered some interesting data:

- $96 \%$ of people sold their kidneys to pay off debt

- $74 \%$ of people who sold their kidneys still had debt 6 years later

- $86 \%$ of people reported a deterioration in their health status after donation

- $79 \%$ would not recommend to others that they sell their kidneys ${ }^{79}$

Arguments that favor the buying and selling of human organs are scarce, but a few do exist. Robert Veatch's book, Transplant Ethics, argues that the United States has 
the money and resources to eliminate socioeconomic disparities, and if this were done, people could then sell their organs, because it is poverty that requires people to act out in desperation for money and not with an objective and informed mind. ${ }^{80}$

Another argument that does not object to the purchase of organs suggests that payments aren't necessarily a bad idea if they work to increase the number of donated organs. The position contends that donating an organ is a relatively small burden compared to the enormous benefit reaped by recipients. ${ }^{81}$

Finally, John Dossetor argues that buying and selling organs is not morally objectionable, but that the system as it exists is inadequate to provide appropriate safeguards. This critique extends not only to the medical system, but also to legal and religious safeguarding organizations as well. ${ }^{82,83}$

In June of 2003, the American Medical Association (AMA) testified before the United States Congress that the shortage of organs is so critical in America, that studies need to be conducted on the effectiveness and outcomes associated with incentivized donations, including possible financial incentives. The AMA does not endorse incentives, they stress, but want to encourage research in the field. ${ }^{84}$ This testimony is likely to influence organ donation policy research in the near future. 


\section{Alternative organ sources}

With the state of discrepancy between organ donors and people waiting for an organ transplant, researchers and advocates have begun to consider non-traditional donation. Some potential non-traditional sources of organs are:

1. ANIMAL ORGANS - Animals are a potential source of donated organs. Experiments with baboon hearts and pig liver transplants have received extensive media attention in the past. One cautionary argument in opposition to the use of animal organs concerns the possibility of transferring animal bacteria and viruses to

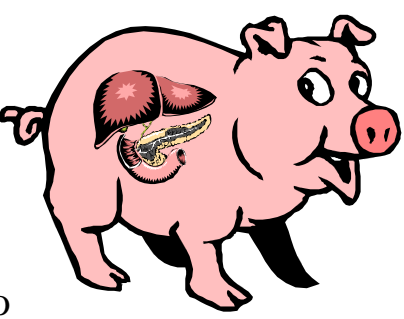
humans.

2. ARTIFICIAL ORGANS - Artificial organs are yet another potential option. The ethical issues involved in artificial organs often revert to questions about the cost and effectiveness of artificial organs. People who receive artificial organ transplants might require further transplanting if there is a problem with the device.

3. STEM CELLS - Stem cells are cells that can specialize into the many different cells found in the human body. Researchers have great hopes that stem cells can one day be used to grow entire organs, or at least groups of specialized cells. ${ }^{85}$ The ethical objections concerning stem cells have focused primarily on their source. While stem cells can be found in the adult human body, the seemingly most potent stem cells come from the first few cells of a human embryo. When the stem cells are removed, the embryo is destroyed. Some people find this practice morally objectionable and would like to put a stop to research and medical procedures that destroy human embryos in the process.

4. ABORTED FETUSES - Aborted fetuses are a proposed source of organs. Debates address whether it is morally appropriate to use organs from a fetus aborted late in a pregnancy for transplantation that could save the life of another infant. Many people believe that this practice would condone late-term abortions, which some individuals and groups find morally objectionable. Another objection comes from people who fear that encouraging the use of aborted fetal 
organs would encourage "organ farming," or the practice of conceiving a child with the intention of aborting it for its organs. 


\section{LEGAL AND SOCIAL ISSUES}

\section{CURRENT LAWS}

Organ donation laws at the state and federal levels exist for two primary purposes. The first purpose of organ donation laws is to help ensure a safe and fair organ donation collection and distribution practice. The second type of organ donation laws have been enacted to widen the pool of potential donors in an effort to increase the number of organs available for transplant.

\section{National Organ Transplant Act of 1984}

The goal of the National Organ Transplant Act (NOTA) was to address the problems of organ shortage and improve the collection and distribution of organs nationwide. It was passed by the United States Congress in 1984.

- Established the United Network for Organ Sharing (UNOS) to maintain a nationwide computer registry of all patients who need organs.

- Established the Organ Procurement and Transplant Network (OPTN) OPTN keeps a national registry of patients and organs and matches organs with patients.

- Established the Task Force on Organ Transplantation.

- Banned the purchase or sale of organs or tissues. ${ }^{86}$

\section{Consolidated Omnibus Reconciliation Act of 1986}

The Consolidated Omnibus Reconciliation Act (COBRA), passed by the United States Congress in 1986, primarily addressed health benefits and health insurance coverage. Regulations concerning organ transplantation and allocation were written into the COBRA reforms:

- Requires hospitals to establish a relationship with a federally mandated Organ Procurement Organization. The Act also includes the instruction that Organ Procurement Organizations must work with hospitals to coordinate transplants at the local level. 
- This act forced all hospitals receiving Medicare or Medicaid funding to enact a "required request" policy. A required request policy ensures that all families of potential donors are told about organ donation and their right to decline donation. ${ }^{87,88}$

\section{Uniform Anatomical Gift Act}

The Uniform Anatomical Gift Act is a set of model regulations and laws concerning organ donation that all 50 states have passed in some measure. There have been many revisions to the Act.

- 1968 - The passage of the Uniform Anatomical Gift Act in the United States Congress allows people to donate their organs.

- 1972 - The Uniform Donor Card is passed as a legal document in all 50 states, allowing anyone over 18 to donate their organs. ${ }^{89}$

\section{MEDICARE Conditions of Participation}

Medicare developed five incentive policies in 1998 to encourage organ donation and organ procurement in participating hospitals. They are printed on the International Association for Organ Donation website:

- "The hospital must notify the organ procurement agency of every death occurring in their facility.

- All hospital personnel providing the option of donation to families will be trained by the organ procurement agency.

- The Hospital will have a written agreement to work with organ, tissue and eye banks.

- The hospital will acknowledge that screening for potential donors will be conducted by the appropriate recovery agency.

- The hospital will work in conjunction with recovery agency to conduct record reviews to determine the donation potential of individual facilities." ${ }^{\prime 0}$ 


\section{First Person Consent Laws}

In the 1990's, states began to pass first person consent laws. These laws require hospitals and organ procurement organizations to follow a patient's organ donation wishes as indicated on their driver's license or in a health care directive. Where the laws are enacted, the hospital and the organ procurement organization has a legal right to follow a deceased person's written organ donation wishes and does not require them to approach the deceased person's family for permission to remove the organs.

Some advocacy organizations suggest that as many as $2 / 3$ of people who sign organ donation consent forms do not have their wishes honored when they die. ${ }^{91}$ This is because when families are approached for consent to remove the organs, they do not give it. The first person consent laws attempt to eliminate the discrepancies between a person's organ donation wishes and family consent by putting the patient's decisions above the decisions of their family. This practice supports and acknowledges autonomy. Autonomy is the right to make decisions for oneself and to practice self-determination and self-governance. Many Americans value autonomy very highly and consider selfdetermination a fundamental right.

\section{THE IMPACT OF TRANSPLANTATION}

Receiving an organ donated from a living or deceased donor is a life changing event. Organ donation impacts a staggering number of people and the stories of how organ transplantation has affected someone's life are often collected to be shared with others. You can read about the impact of organ transplantation in the following resources:

- The United Network for Organ Sharing website has stories of donors and recipients. http://www.transplantliving.org/patientProfile.asp

- TransWeb.org is a website "...all about transplantation and donation." They have recipient and donor stories on their website under the heading "Real People." www.transweb.org

- Dick A. Hawkin's Liver Transplant is a web page published by a man who received a liver transplant. It tells his story. There are several similar pages out there published by people who wish to share their experiences. This particular website is located at www.sadiehawkins.com/liver.htm 


\section{OTHER MATERIALS}

\section{BOOKS}

The Ethics of Organ Transplants: The Current Debate. By Arthur Caplan. Prometheus Books, 1999.

Transplantation Ethics. By Robert Veatch. Georgetown University Press; Reprint edition, 2002.

\section{ARTICLES}

Ankeny RA. Recasting the debate on multiple listing for transplantation through consideration of both principles and practice. Cambridge Quarterly of Healthcare Ethics. 8(3):330-9, 1999 Summer.

Anonymous. Ethicists say yes to transplants for HIV-positive patients. AIDS Policy \& Law. 17(16):9, 2002 Aug 30.

Anonymous. The Muslim Law (Shariah) Council and organ transplants. Accident \& Emergency Nursing. 4(2):73-5, 1996 Apr.

Barker JH, Polcrack L. Respect for persons, informed consent and the assessment of infectious disease risks in xenotransplantation. Medicine, Health Care \& Philosophy. 4(1):53-70, 2001.

Bartz CE. Operation Blue, ULTRA: DION--The Donation Inmate Organ Network. Kennedy Institute of Ethics Journal. 13(1), 2003 Mar.

Beaulieu D. Organ donation: the family's right to make an informed choice. Journal of Neuroscience Nursing. 31(1):37-42, 1999 Feb.

Browning CJ, Thomas SA. Community values and preferences in transplantation organ allocation decisions. Social Science \& Medicine. 52(6):853, 2001 Mar 15.

Burd L, Gregory JM, Kerbeshian J. The brain-mind quiddity: ethical issues in the use of human brain tissue for therapeutic and scientific purposes. Journal of Medical Ethics. 24(2):118-22, 1998 Apr.

Calne R. Animal organ transplants. British Journal of Hospital Medicine. 57(3):66-7, 1997 Feb 5-18. 
Childress JF. Ethics and the Allocation of Organs for Transplantation. Kennedy Institute of Ethics Journal. 6(4), 1996 Dec.

Childress JF. Putting patients first in organ allocation: an ethical analysis of the U.S. debate.Cambridge Quarterly of Healthcare Ethics. 10(4):365-76, 2001 Fall.

Cohen CB. Public Policy and the Sale of Human Organs. Kennedy Institute of Ethics. 12(1), 2002 Mar.

Cohen EP, Rosendale JD, Bong CJH, et.al. Benefit of Child-to-Parent Kidney Donation. American Journal of Transplantation. 3(7):865-872, 2003 Jul.

Corley MC, Westerberg N, Elswick RK Jr, et.al. Rationing organs using psychosocial and lifestyle criteria. Research in Nursing \& Health. 21(4):327-37, 1998 Aug.

Corson T. The Telltale Heart: The strange case of organ transplantation in Japan. Transition. 9(4), 2000.

Daar AS. Animal-to-human organ transplants--a solution or a new problem? Bulletin of the World Health Organization. 77(1):54-61, 1999.

Daar AS. Quest for organ donors: development of transplant ethics. Transplantation Proceedings. 30(7):3616, 1998 Nov.

De WG, Berghmans RL, Boer GJ, et.al. Ethical guidance on human embryonic and fetal tissue transplantation: a European overview. Medicine, Health Care \& Philosophy. 5(1):79-90, 2002.

Dickenson D, Widdershoven G. Ethical issues in limb transplants. Bioethics. 15(2):11024, 2001 Apr.

Deutsch LB. Medicaid payment for organ transplants: the extent of mandated coverage. Columbia Journal of Law \& Social Problems. 30(2):185-213, 1997 Winter.

Dudzinski DM. Does the Respect for Donor Rule Respect the Donor? The American Journal of Bioethics. 3(1), 2003 Winter.

Egan TM. Ethical Issues in Thoracic Organ Distribution for Transplant. American Journal of Transplantation. 3(4):366-372, 2003 Apr.

Etzioni A. Organ Donation: A Communitarian Approach. Kennedy Institute of Ethics. 13(1), 2003 Mar.

Giacomini M.A change of heart and a change of mind? Technology and the redefinition of death in 1968. Social Science and Medicine. 44(10):1465-1482, 1997 May. 
Gill MB. Paying for Kidneys: The Case against Prohibition. Kennedy Institute of Ethics. 12(1), 2002 Mar.

Giuliano KK. Organ transplants. Tackling the tough ethical questions. Nursing. 27(5):349; quiz 40, 1997 May.

Glannon W. Responsibility, alcoholism, and liver transplantation. The Journal of Medicine and Philosophy. 23(1):31, 1998 Feb.

Gordon EJ. "They don't have to suffer for me": why dialysis patients refuse offers of living donor kidneys. Medical Anthropology Quarterly. 15(2):245-67, 2001 Jun.

Kluge EH. Improving organ retrieval rates: various proposals and their ethical validity. Health Care Analysis. 8(3):279-95, 2000.

Himma KE. A critique of UNOS liver allocation policy. United Network for Organ Sharing. Cambridge Quarterly of Healthcare Ethics. 8(3):311-20, 1999 Summer.

Holland S. Contested Commodities at Both Ends of Life: Buying and Selling Gametes, Embryos, and Body Tissues. Kennedy Institute of Ethics. 11(3), 2001 Sep.

Jawad F, Hussain Z, Ahmed E, et.al. Problems of donor selection in a living related renal transplant program - Ethics, Justice and Commerce. Transplantation Proceedings. 30(7):3643-3643(1), 1998 Nov.

Joralemon D. Shifting ethics: debating the incentive question in organ transplantation. Journal of Medical Ethics. 27(1):30-5, 2001 Feb.

Kahn J. The Ethics of Organ Transplantation for Prisoners. Seminars in Dialysis, 2003; (16)5:365.

Kahn JP. Three Views of Organ Procurement Policy: Moving Ahead or Giving Up? Kennedy Institute of Ethics. 13(1), 2003 Mar.

Koenig BA. Dead Donors and the "Shortage" of Human Organs: Are We Missing the Point? The American Journal of Bioethics. 3(1), 2003 Winter.

Kolata G. In shift, prospects for survival will decide liver transplants. New York Times. :A1, A26, 1996 Nov 15.

Koppelman ER. The Dead Donor Rule and the Concept of Death: Severing the Ties That Bind Them. The American Journal of Bioethics. 3(1), 2003 Winter.

Kuczewski MG. The Gift of Life and Starfish on the Beach: The Ethics of Organ Procurement. The American Journal of Bioethics. 2(3), 2002 Summer. 
Lee D. Organ transplants. Unconditional surrender. Health Service Journal. 109(5670):suppl 4-5, 1999 Sep 2.

Lock M. Human body parts as therapeutic tools: contradictory discourses and transformed subjectivities. Qualitative Health Research. 12(10):1406-18, 2002 Dec.

Martin DK, Meslin E. The give and take of organ procurement. The Journal of Medicine and Philosophy. 19(1):61, 1994 Feb.

Matas AJ, Bartlett ST, Leichtman AB, et.al. Morbidity and Mortality After Living Kidney Donation, 1999-2001: Survey of United States Transplant Centers. American Journal of Transplantation., 3(7):830-834, July 2003.

Mata AJ, Garvey CA, Jacobs CL, et.al. Nondirected Donation of Kidneys from Living Donors. New England Journal of Medicine, 2000; 343(6):433-436.

Mathieson PW, Jolliffe D, Jolliffe R, et.al. The spouse as a kidney donor: ethically sound? Nephrology Dialysis Transplantation. 14(1):46-8, 1999 Jan.

McCarrick PM. Incentives for Providing Organs. Kennedy Institute of Ethics Journal. 13(1), 2003 Mar.

Miranda B, Matesanz R. International issues in transplantation. Setting the scene and flagging the most urgent and controversial issues. Annals of the New York Academy of Sciences. 862:129-43, 1998 Dec 30.

Murphy TF. The ethics of multiple vital organ transplants. Hastings Center Report. 32(2):47-8, 2002 Mar-Apr.

Northoff G. Do brain tissue transplants alter personal identity? Inadequacies of some "standard" arguments. Journal of Medical Ethics. 22(3):174-80, 1996 Jun.

Orr RD, Johnston JK, Ashwal S, et.al. Should children with severe cognitive impairment receive solid organ transplants? Journal of Clinical Ethics. 11(3):219-29, 2000 Fall.

Purdy L. The risks of animal-human transplants: why they may be a bad idea. Free Inquiry. 19(4):38-41, 1999 Fall.

Randall T. Successful liver transplantation in older patients raises new hopes, challenges, ethics questions. JAMA. 264(4):428-430, 1990.

Reiss MJ. The ethics of xenotransplantation. Journal of Applied Philosophy. 17(3):25362, 2000. 
Russell BJ. Fair distribution and patients who receive more than one organ transplant. Journal of Clinical Ethics. 13(1):40-8, 2002 Spring.

Sanders LM, Giudice L, Raffin TA. Ethics of fetal tissue transplantation. The Western Journal of Medicine. 159(3):400, 1993 Sep.

Scheper-Hughes N. The Ends of the Body--Commodity Fetishism and the Global Traffic in Organs. SAIS Review. 22(1), 2002 Winter-Spring.

Scheper-Hughes N. The Global Traffic in Human Organs. Current Anthropology. 41(2):191, 2000 Apr.

Schmidt VH. Selection of recipients for donor organs in transplant medicine. (Issues in Clinical Ethics). The Journal of Medicine and Philosophy. 23(1):50, 1998 Feb.

Shapiro JP. Who cares how high her IQ really is: disabled Sandra Jensen just wants to live. U.S. News \& World Report Sept 11, 1995 119(10):59.

Siminoff LA. African-American Reluctance to Donate: Beliefs and Attitudes about Organ Donation and Implications for Policy. Kennedy Institute of Ethics Journal. 10(1), 2000 Mar.

Spike J.Cultural Diversity and Patients with Reduced Capacity: The Use of Ethics Consultation to Advocate for Mentally Handicapped Persons in Living Organ Donation. Theoretical Medicine and Bioethics. 22(6):519-526, 2001,

Switzer GE, Dew MA, Butterworth VA, et.al. Understanding donors' motivations: a study of unrelated bone marrow donors. Social Science \& Medicine. 45(1):137-47, 1997 Jul.

Taylor JS. Autonomy, Constraining Options, and Organ Sales. Journal of Applied Philosophy. 19(3):273-285, 2002.

Thomasma DC, Micetich KC, Brems J, et.al. The ethics of competition in liver transplantation. Cambridge Quarterly of Healthcare Ethics. 8(3):321-9, 1999 Summer.

Ubel PA, Loewenstein G. Distributing scarce livers: the moral reasoning of the general public. Social Science and Medicine. 42(7):1049-1055, 1996 Apr.

Ubel PA, Loewenstein G.The efficacy and equity of retransplantation: an experimental survey of public attitudes. Health Policy. 34(3):145-151, 1995 Nov.

Ubel PA. Transplantation in alcoholics: separating prognosis and responsibility from social biases. Liver Transplantation \& Surgery. 3(3):343-6, 1997 May. 
Veatch RM. A New Basis for Allocating Livers for Transplant. Kennedy Institute of Ethics Journal. 10(1), 2000 Mar.

Veatch RM. Why Liberals Should Accept Financial Incentives for Organ Procurement. Kennedy Institute of Ethics Journal. 13(1), 2003 Mar.

Zucker A. Allocation. (allocation of drugs and organ transplants). Death Studies. 18(3):305, 1994 May-Jun. 


\section{GLOSSARY}

Definitions adapted from the Yahoo! American Heritage ${ }^{\circledR}$ Dictionary. ${ }^{92}$

Antibodies - Antibodies are a protein released into the blood stream to fight off a foreign agent in the body.

Autonomy - The practice of independent decision making, self-governance and selfdetermination.

Brain death - The ceasing of all brain function.

Cadaver - Latin for "a dead body."

Graft - To transplant or surgically insert a living body part into an existing organ or body part to compensate for damage or a defect.

Holistic - The act of emphasizing the importance of the whole.

Immunosuppressant drugs - Immunosuppressant drugs suppress the body's immune system response.

Life years - In medical economics, life years refer to the number of years of life either gained or lost due to a medical therapy that would not have occurred without the medical intervention.

Mandated choice - The approach to organ donation where every citizen must declare their wishes regarding organ donation.

Nondirected donation (NDD) - An organ donation initiated by an individual who approaches a transplant center or an organ procurement organization and offers to donate a kidney to any stranger who may need it.

OPO - OPO stands for "organ procurement organization." They are federally mandated organizations that collect organs from hospitals and deliver them to the appropriate transplant candidate.

Organ - An organ is a part of the body that performs a specific function.

Organ transplant - The removal and replacement of a damaged organ with a healthy one.

Presumed consent - The approach to organ donation whereby every citizen is considered an organ donor unless they specifically request not to be. 
Rejection - The body rejects a transplanted organ because it considers it a harmful foreign object and sends antibodies out to kill it and prevent its functioning.

UNOS - UNOS stands for the "United Network for Organ Sharing." This organization was established by the U.S. government to maintain a national list of people awaiting transplants.

Xenotransplantation - Transplanting an animal organ into a human being. 


\section{REFERENCES}

${ }^{1}$ Minnesota Medical Association website. http://www.mnmed.org/News/fullstory.cfm?recNum=2777. Accessed 12/16/03.

${ }^{2}$ Department of Health and Human Services Organ Donation website. www.organdonation.gov. Accessed 11/5/03.

${ }^{3}$ Living Donors On-line website. www.livingdonorsonline.org. Accessed 11/05/03.

${ }^{4}$ Adams PL, Cohen DJ, Danovitch DM, et.al. The nondirected live-kidney donor: Ethical considerations and practice guidelines: A National Conference Report. Transplantation, 2002; 74(4):582-589.

${ }^{5}$ UNOS website. www.unos.org. Accessed 5/30/03.

${ }^{6}$ UNOS website. www.unos.org. Accessed 5/30/03.

${ }^{7}$ Douglas DD. Should Everyone Have Equal Access to Organ Transplantation? An Argument in Favor. Archives of Internal Medicine, 2003; 163:1883-1885. ${ }^{8}$ The United Network for Organ Sharing website. www.unos.org. Accessed 11/20/03.

${ }^{9}$ The Transplant Network website. http://www.thetransplantnetwork.com/history of transplantation.htm. Accessed $5 / 28 / 03$.

${ }^{10}$ The Transplant Network website. http://www.thetransplantnetwork.com/history of transplantation.htm. Accessed $5 / 28 / 03$.

${ }^{11}$ The Transplant Network website. http://www.thetransplantnetwork.com/history of transplantation.htm. Accessed $5 / 28 / 03$.

${ }^{12}$ The Transplant Network website. http://www.thetransplantnetwork.com/history_of_transplantation.htm. Accessed $5 / 28 / 03$.

${ }^{13}$ Gift of Life Donor Program website. http://www.donors1.org/donation/history.html. Accessed 5/28/03.

${ }^{14}$ Gift of Life Donor Program website. http://www.donors1.org/donation/history.html. Accessed 5/28/03.

${ }^{15}$ The Transplant Network website. http://www.thetransplantnetwork.com/history of transplantation.htm. Accessed $5 / 28 / 03$.

${ }^{16}$ The Transplant Network website. http://www.thetransplantnetwork.com/history of transplantation.htm. Accessed $5 / 28 / 03$.

${ }^{17}$ The Transplant Network website. http://www.thetransplantnetwork.com/history of transplantation.htm. Accessed $5 / 28 / 03$.

${ }^{18}$ The Transplant Network website. http://www.thetransplantnetwork.com/history of transplantation.htm. Accessed $5 / 28 / 03$. 
${ }^{19}$ The Transplant Network website. http://www.thetransplantnetwork.com/history of transplantation.htm. Accessed 5/28/03.

${ }^{20}$ The Transplant Network website. http://www.thetransplantnetwork.com/history of transplantation.htm. Accessed 5/28/03.

${ }^{21}$ Gift of Life Donor Program website. http://www.donors1.org/donation/history.html. Accessed 5/28/03.

${ }^{22}$ Transweb.org website. http://www.transweb.org/reference/articles/donation/nacta.html. Accessed $5 / 28 / 03$.

${ }^{23}$ Transweb.org website. http://www.transweb.org/reference/articles/donation/nacta.html. Accessed 5/28/03.

${ }^{24}$ Department of Health and Human Services website. http://www.hhs.gov/news/press/1998pres/980617.html. Accessed 5/30/03.

${ }^{25}$ Childress JF. The Failure to Give: Reducing Barriers to Organ Donation. Kennedy Institute of Ethics Journal, 2001; 11(1):1-16.

${ }^{26}$ United Network for Organ Sharing: Fact Sheets website. http://www.unos.org/Resources/FactSheets.asp. Accessed 6/2/03.

${ }^{27}$ CNN Ethics Matters, "Making Organ Donation a Better Deal," website. http://www.cnn.com/2002/HEALTH/06/25/ethics.matters/index.html. Accessed 7/21/03.

${ }^{28}$ Childress JF. The Failure to Give: Reducing Barriers to Organ Donation. Kennedy Institute of Ethics Journal, 2001; 11(1):1-16.

${ }^{29}$ Hauptman PJ, O'Connor K. Procurement and allocation of solid organs for transplantation. New England Journal of Medicine, 1997; 336:422-431.

${ }^{30}$ The Stanford Encyclopedia of Philosophy webpage. http://plato.stanford.edu/entries/justice-distributive/. Accessed 11/20/03.

${ }^{31}$ University of Washington School of Medicine website. http://eduserv.hscer.washington.edu/bioethics/tools/princpl.html\#prin4. Accessed $11 / 13 / 03$.

${ }^{32}$ Benjamin M. Medical Ethics and Economics of Organ Transplantation. Health Progress, 1988; 69(2):47-52.

${ }^{33}$ Douglas DD. Should Everyone Have Equal Access to Organ Transplantation? An Argument in Favor. Archives of Internal Medicine, 2003; 163:1883-1885.

${ }^{34}$ Saint-Arnaud J. Ethical Analysis of Arguments Supporting the Use of Certain Exclusion Criteria in Organ Transplantation. Canadian Journal of Cardiovascular Nursing, 1997; 8(2):9-12.

${ }^{35}$ Kluge EH. Drawing the Ethical Line Between Organ Transplantation and Lifestyle Abuse. Canadian Medical Association Journal, 1994; 150(5):745-746.

${ }^{36}$ Neuberger J. Should liver transplantation be made available to everyone? The case against. Archives of Internal Medicine, 2003; 163:1881-1883. 
${ }^{37}$ Williams A. The rationing debate: Rationing health care by age: The case for. British Medical Journal, 1997; 314:820.

${ }^{38}$ Ubel PA, Arnold RM, Caplan AL. Rationing failure: Retransplantation of scarce, vital organs in the US. Journal of the American Medical Association, 1993; 270:24692474.

${ }^{39}$ Childress JF. Putting Patients First in Organ Allocation: An Ethical Analysis of the U.S. Debate. Cambridge Quarterly of Healthcare Ethics, 2001; 10(4):365-376.

${ }^{40}$ Childress JF. Putting Patients First in Organ Allocation: An Ethical Analysis of the U.S. Debate. Cambridge Quarterly of Healthcare Ethics, 2001; 10(4):365-376.

${ }^{41}$ Small R. The ethics of life expectancy. Bioethics, 2002; 16(4):307-34.

${ }^{42}$ Hauptman PJ, O'Connor K. Procurement and allocation of solid organs for transplantation. New England Journal of Medicine, 1997; 336:422-431.

${ }^{43}$ United Network for Organ Sharing website. www.unos.org. Accessed 8/13/03.

${ }^{44}$ Childress JF. Putting Patients First in Organ Allocation: An Ethical Analysis of the U.S. Debate. Cambridge Quarterly of Healthcare Ethics, 2001; 10(4):365-376.

${ }^{45}$ CNN Ethics Matters website. Kahn J. "Where have all the organs gone?" http://www.cnn.com/2001/HEALTH/04/30/ethics.matters/. Accessed November 12, 2003.

${ }^{46}$ Michael C. Kearl's website. http://www.trinity.edu/ mkearl/deathmed.html. Accessed $8 / 29 / 03$.

${ }^{47}$ Benjamin M. Medical ethics and economics of organ transplantation. Health Progress, 1988; 69(2):47-52.

${ }^{48}$ McChesney LP. Braithwaite SS. Expectations and outcomes in organ transplantation. Cambridge Quarterly of Healthcare Ethics. 8(3):299-310, 1999 Summer.

${ }^{49}$ Childress JF. The Failure to Give: Reducing Barriers to Organ Donation. Kennedy Institute of Ethics Journal, 2001; 11(1):1-16.

${ }^{50}$ New York Organ Donor Network: Legislation UAGA 1968 website. http://www.nyodn.org/organ/l legispass.html. Accessed 7/7/03.

${ }^{51}$ Organ Procurement and Transplant Network website. http://www.optn.org/latestData/step2.asp?. Accessed 7/7/03.

${ }^{52}$ Siminoff LA, Mercer MB. Public Policy, Public Opinion, and Consent for Organ Donation. Cambridge Quarterly of Healthcare Ethics, 2001; 10(4):377-386.

${ }^{53}$ Siminoff LA, Mercer MB. Public Policy, Public Opinion, and Consent for Organ Donation. Cambridge Quarterly of Healthcare Ethics, 2001; 10(4):377-386.

${ }^{54}$ Kennedy I, Sells RA, et.al. The case for 'presumed consent' in organ donation. Lancet, 1998; 351(9116): 1650-1652.

${ }^{55}$ Hill DJ, Palmer TC, Evans DW. Presumed Consent. If this is introduced, people will have to have all relevant information. British Medical Journal, 1999; 318(7196): 1490.

${ }^{56}$ Siminoff LA, Mercer MB. Public Policy, Public Opinion, and Consent for Organ Donation. Cambridge Quarterly of Healthcare Ethics, 2001; 10(4):377-386.

${ }^{57}$ Arnold R, Bartlett S, Bernat J, et.al. Financial incentives for cadaver organ donation: An ethical reappraisal. Transplantation, 2002; 73(8):1361-1367. 
${ }^{58}$ Delmonico FL, Arnold R, Scheper-Hughes N, et.al. Ethical Incentives - Not Payment for Organ Donation. New England Journal of Medicine, 2002; 346(25):20022005.

${ }^{59}$ Veatch RM. Gift or Salvage: The Two Models or Organ Procurement. Transplant Ethics, pp. 143-166; Georgetown University Press: Washington, DC, 2000.

${ }^{60}$ Etzioni A. Organ Donation: A Communitarian Approach. Kennedy Institute of Ethics Journal, 2003; 13(1):1-18.

${ }^{61}$ Cameron JS, Hoffenberg R. The ethics of organ transplantation reconsidered: Paid organ donation and the use of executed prisoners as donors. Kidney International, 1999; 55(2):724-732.

${ }^{62}$ Bartz CE. Operation Blue, ULTRA: DION - the donation inmate organ network. Kennedy Institute of Ethics Journal, 2003; 13(1):37-43.

${ }^{63}$ Robertson JA. The Dead Donor Rule. The Hasting Center Report, 1999; 29(6):6-14.

${ }^{64}$ Miller RB. Ethics of paid organ donation and the use of executed prisoners as donors: A dialectic with Professors Cameron and Hoffenberg. Kidney International, 1999; 55:733-737.

${ }^{65}$ Hillman H. Harvesting organs from recently executed prisoners: Practice must be stopped. British Medical Journal, 2001; 323(7323):1254.

${ }^{66}$ Cameron JS, Hoffenberg R. The ethics of organ transplantation reconsidered: Paid organ donation and the use of executed prisoners as donors. Kidney International, 1999; 55(2):724-732.

${ }^{67}$ United Network for Organ Sharing Transplant Living website. www.transplantliving.org/livingDonation. Accessed 7/7/03.

${ }^{68}$ Vastag B. Living-donor transplants reexamined: experts cite growing concerns about safety of donors. JAMA. 290(2):181-2, 2003 Jul 9.

${ }^{69}$ The Organ Procurement and Transplant Network website. http://www.optn.org/about/donation/livingDonation.asp\#facts. Accessed $11 / 20 / 03$.

${ }^{70}$ Vastag B. Living-donor transplants reexamined: experts cite growing concerns about safety of donors. JAMA. 290(2):181-2, 2003 Jul 9.

${ }^{71}$ The Authors for the Live Organ Donor Consensus Group. Consensus Statement on the Live Organ Donor. JAMA, 2000; 284:2919-2926.

${ }^{72}$ Spital A. Justification of living-organ donation requires benefit for the donor that balances the risk: Commentary on Ross et al. Transplantation, 2002; 74(3):423424.

${ }^{73}$ Kuczewski MG. The gift of life and starfish on the beach: The ethics of organ procurement. American Journal of Bioethics, 2002; 2(3):53-56.

${ }^{74}$ Delmonico FL, Arnold R, Scheper-Hughes N, et.al. Ethical incentives - not payment for organ donation. New England Journal of Medicine, 2002; 346(25):2002-2005.

${ }^{75}$ The Badger Herald On-line website. http://www.badgerherald.com. Accessed 2/2/03.

${ }^{76}$ Cohen CB. Public Policy and the Sale of Human Organs. Kennedy Institute of Ethics Journal, 2002; 12(1):47-64.

${ }^{77}$ Naqvi A. Rizvi A. Against paid organ donation. Transplantation Proceedings, 2001; 33(5):2628. 
${ }^{78}$ The United Network for Organ Sharing website. www.unos.org. Accessed 11/2/03.

${ }^{79}$ Goyal M, Mehta RL, Schneiderman LJ, et.al. Economic and health consequences of selling a kidney in India. JAMA, 2002; 288(13):1589-1593.

${ }^{80}$ Veatch RM. Gift or Salvage: The Two Models or Organ Procurement. Transplant Ethics, pp. 143-166; Georgetown University Press: Washington, DC, 2000.

${ }^{81}$ Kuczewski MG. The gift of life and starfish on the beach: The ethics of organ procurement. American Journal of Bioethics, 2002; 2(3):53-56.

${ }^{82}$ Dossetor JB. Rewarded gifting: Is it ever ethically acceptable? Transplantation Proceedings, 1992; 24(5):2092-2094.

${ }^{83}$ Phadke KD, Anandh U. Ethics of paid organ donation. Pediatric Nephrology, 2002; 17(5):309-311.

${ }^{84}$ American Medical Association website. http://www.amaassn.org/ama/pub/article/1987-7737.html\#1. Accessed 7/21/03.

${ }^{85}$ Center for Bioethics Reading Packet Human Stem Cells: An Ethical Overview website. http://www.bioethics.umn.edu/publications/Stem_Cells.pdf. Accessed 11/20/03.

${ }^{86}$ International Association for Organ Donation website. http://www.iaod.org/understanding-organ-donation-laws.htm. Accessed 6/23/03.

${ }^{87}$ International Association for Organ Donation website. http://www.iaod.org/understanding-organ-donation-laws.htm. Accessed 6/23/03.

${ }^{88}$ New York Organ Donor Network website. http://www.nyodn.org/organ/l_legispass_5.html. Accessed 8/20/03.

${ }^{89}$ The Transplant Network website. www.thetransplantnetwork.com. Accessed 8/20/03.

${ }^{90}$ International Association for Organ Donation website. http://www.iaod.org/understanding-organ-donation-laws.htm. Accessed 6/23/03.

${ }^{91}$ American Kidney Fund website. http://www.akfinc.org/AboutAKF/AboutAKF.htm. Accessed 10/8/03.

${ }^{92}$ Yahoo! American Heritage ${ }^{\circledR}$ Dictionary website. http://education.yahoo.com/reference/dictionaryl. Accessed June-September, 2003. 
Ethics of Organ Transplantation is an original publication by the University of Minnesota's Center for Bioethics. Special thanks to the following:

The Starr Foundation

Brenda Paul, MS Research Assistant, Center for Bioethics

Maryam Valapour, MD Faculty, Center for Bioethics

Dianne Bartels, $\mathrm{PhD}, \mathrm{MA}, \mathrm{RN} \sim$ Associate Director, Center for Bioethics

Ariel Abbott-Penny Resource Center Coordinator, Center for Bioethics

Jeffrey Kahn, PhD, MPH Director, Center for Bioethics

Additional publications can be found at the Center for Bioethics' website:

www.bioethics.umn.edu

Or by contacting the Center for Bioethics at (612) 624-9440 